\title{
Trisomy 10
}

National Cancer Institute

\section{Source}

National Cancer Institute. Trisomy 10. NCI Thesaurus. Code C81729.

A chromosomal abnormality consisting of the presence of a third copy of chromosome 10 in somatic cells. 